\title{
SINERGISITAS PENDIDIKAN ISLAM: Model Sinergisitas Lembaga Pendidikan Islam di Indonesia
}

\author{
Ilham \\ Fakultas Tarbiyah IAI Muhammadiyah Bima \\ ilhamham903@gmail.com
}

\section{Abstrak}

Memperbincangkan pendidikan Islam sebagai sebuah keilmuan tidak pernah berhenti untuk dikaji dan selalu dimanis seiring dengan tingkat perkembangan kehidupan manusia yang semakin maju. Pendidikan Islam sebagaimana dipahami adalah sebagai proses transformasi dan internalisasi ilmu pengetahuan dan nilai-nilai pada manusia melalui penumbuhan dan pengembangan potensi fitrahnya guna mencapai keselarasan dan kesempurnaan hidup dalam segala aspeknya. Maka upaya dalam mencari format senergisitas pelaksanaan pendidikan Islam untuk mencapai pengembangan potensi fitrah manusia perlu ditelaah dalam berbagai aspek dan dimensi baik kiprah lembaga pendidikan Islam sebagai institusi maupun metode pengajarannya.Oleh karena itu, nampaknya upaya mencari sinergisitas yang tepat dalam peningkatan mutu pendidikan Islam adalah sesuatu yang sangat penting dilakukan. Hal ini, didukung oleh salah satu potensi positif yang dimiliki lembaga pendidikan Islam adalah karakteristiknya yang fleksibel, sehingga mudah diadaptasikan dalam suatu pelaksanaan pembelajaran. Selain itu, berbagai kelemahan terhadap pendidikan Islam dapat dijadikan sebagai starting point dan standar untuk melakukan perbaikan, baik dari aspek manajemen maupun kurikulumnya, yang kemudian diakomodasikan secara akultural dengan kebutuhan dan perkembangan masyarakat.

Kata Kunci:Model sinergisitas, Pendidikan Islam, Lembaga Pendidikan Islam

\section{Pendahuluan.}

$\mathrm{S}$ ecara historis, lembaga pendidikan Islam di Indonesia memiliki corak dan bentuk yang berbeda walaupun perbedaan bukan berarti tidak sama, paling tidak semangat para praktisi tokoh (ulama) untuk melaksanakan pendidikan Islam membawa rahmat dalam mencerdaskan anak bangsa khususnya penanaman iman dan taqwa (imtaq) baik secara formal maupun non-formal. Nor Huda, mengklasifikasi pendidikan Islam di Indonesia dari masa pembentukan dan perkembangannya pada pendidikan pesantren, madrasah dan Perguruan Tinggi Agama Islam (PTAI) sebagai pendidikan Islam formal dan keluarga, majelis taklim sebagai pendidikan Islam non-formal. ${ }^{1}$ Dengan melihat keberadaan pendidikan Islam

\footnotetext{
${ }^{1}$ Nor Huda, Sejarah Social Intelektual Islam, (Jakarta, Radjawali Press, 2015), 297
} 
dan lembaga pendidikan Islam di atas, bahwa pendidikan Islam di Indonesia memiliki berbagai macam corak, jenis dan format yang masing-masing bertujuan untuk memberikan pendidikan yang seluas-luasnya kepada peserta didik.Hal ini bertujuan sebagaimana yang dikemukakan oleh Azyumardi Azra, agar pendidikan Islam mampu menyesuaikan diri dengan perkembangan kehidupan masyarakat yang semakin meningkat dan berorientasi pada tantangan kekinian. ${ }^{2}$ Sebab pendidikan Islam ke depan akan terus dihadapkan pada dinamika kehidupan yang semakin maju. Untuk itu lembaga pendidikan Islam sebagai wadah pembinaan mental, kepribadian dan kreatifitas masyarakat Islam harus mampu menyesuaikan diri dengan perkembangan zaman.

Pendidikan dalam pandangan Islam merupakan upaya sadar, terstruktur serta sistematis untuk mensukseskan misi penciptaan manusia sebagai abdullah dan khalifah Allah di muka bumi.Maka, Pendidikan harus merupakan bagian yang tak terpisahkan dari sistem hidup Islam.Sebagai bagian integral dari sistem kehidupan Islam, sistem pendidikan memperoleh masukan dari supra sistem, yakni keluarga dan masyarakat atau lingkungan, dan memberikan hasil/keluaran bagi suprasistem tersebut. Sementara sub-subsistem yang membentuk sistem pendidikan antara lain adalah tujuan pendidikan itu sendiri, anak didik, manajemen, struktur dan jadwal waktu, materi, tenaga pendidik/pengajar dan pelaksana, alat bantu belajar, teknologi, fasilitas, kendali mutu, penelitian dan biaya pendidikan.

Padatulisan ini akan membahas sinergisitas pendidikan Islam. Maksud sinergisitas dalam pendidikan Islam merupakan proses memadukan beberapa aktivitas dalam rangka mencapai satu hasil dalam proses pendidikan Islam. Semua aktivitas pendidikan Islam menghendaki supaya dalam pelaksanaan pendidikan mampu mewarnai suasana keislaman pada semua unsur dalam pendidikan Islam. Sebagai landasan dasar penulisan ini berangkat dari berbagai macam jenis-jenis lembaga pendidikan Islam yang telah dilaksanakan baik pada sekolah, madrasah, pesantren, pendidikan tinggi sebagai lembaga formal dan keluarga, majelis taklim sebagai penddikan non formal.Pada sisi yang lain, bahwa sinergisitas pendidikan Islam yang dimaksud adalah upaya memadukan semua sistem pendidikan Islam sebagai lembaga pendidikan yang betul-betul memberikan dampak pada nilai-nilai pendidikan Islam yang utuh, tidak parsial dan sampai pada tujuan dan hasil yang menjadi harapan dalam menumbuhkan generasi muslim dalam kehidupan umat Islam.Membangun sinergitas baik dalam bentuk pengelolaan, pengajaran maupun manajemen pendidikan Islam menjadi model pendidikan yang ideal.Selanjutnya

\footnotetext{
${ }^{2}$ Azyumardi Azra, Pendidikan Islam: Tradisi Modernisasi Menuju Melinium Baru, (Jakarta, Logos Wacana Ilmu, 1999), 51
} 
sinergisitas akan diarahkan pada konsep keterpaduan pendidikan Islam sebagai jalur formal dan non formal sebagai sebuah sistem baik sekolah, keluarga dan masyarakat dengan konsepmelaluiparadigma model koordinasi-komunikatif, integrasiholistik(integrative-holistic), Sehingga besar harapan dalam membangun pendidikan Islam tersebut menjadi peluang agar sistem pendidikan Islam dalam membangun sumber daya manusia (SDM) yang berperadaban.

\section{Pengertian Sinergisitas Pendidikan Islam}

Kata sinergisitas dalam kamus bahasa Indonesia dapat dipahami dari katasiner-gi memiliki makna kegiatan atau operasi gabungan. Suatu kegiatan yang dilakukan untuk menyatukan dua bahagian yang berbeda. Pada kata yang lain ada juga menyebutkan sinergisme atau bersinergiadalah suatu usaha melakukan kegiatan atau operasi gabungansedangkan kata mengnyinergikan atau meng-nyi-ner-gi-kan bermakna menggiatkan. ${ }^{3}$ Dalam bahasa Arab sinergissemakna dengan kata تآزر (taazuru) artinya memadukan. Secara istilah menyebutkan:

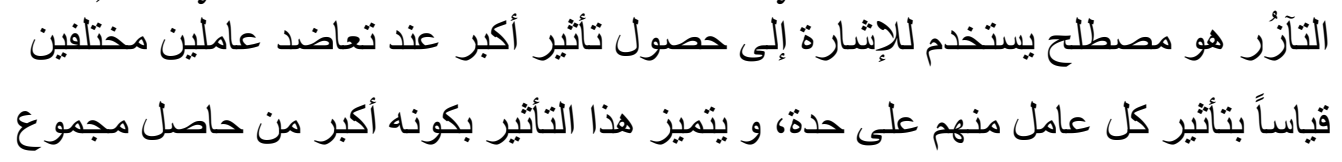

"attaazuradalah istilah yang digunakan untuk merujuk ke dampak yang lebih besar ketika dua faktor yang berbeda dibandingkan dengan efek sinergi dari setiap faktor secara terpisah, dan efek ini ditandai dengan semakin besar terhadap jumlah hasil pencapaian". 4

Murujuk pada konsep di atas, sinergitas merupakan proses memadukan beberapa aktivitas dalam rangka mencapai satu hasil yang berlipat. Keterpaduan dua Aktivitas tersebut tentunya tidak selalu dikerjakan bersamaan, tetapi sangat tergantung karakteristik dari masing-masing aktivitas.Apabila dua aktivitas tersebut bersifat komplementer (saling mengisi), maka memang harus dilakukan bersamaan, karena keduanya saling isi-mengisi.Tetapi apabila dua atau lebih aktivitas tersebut bersifat subsitusi, maka aktivitasnya tidak harus bersamaan, tetapi dapat saling menggantikan, atau bergiliran.Lebih lanjut menurut Hampden-Turner, sebagaimana dikutip oleh Ismail Sholihin, menyatakan bahwa aktivitas sinergi merupakan suatu proses yang melibatkan berbagai aktivitas, yang berjalan bersama sehingga menciptakan sesuatu yang baru. Sinergi merupakan hasil dari suatu relasi dialogik antara berbagai sumber pengetahuan yang berbeda, dan merupakan suatu proses yang

\footnotetext{
${ }^{3}$ W.J.S. Puswadarminta, Kamus Umum Indonesia, (Jakarta, Balai Pustaka, (1976), 955

${ }^{4}$ Ahmad Warson Munawwar, Al-Munawwir,Kamus Arab Indonesia (Cet. 14; Surabaya: Pustaka Progressif, 1997), 432.
} 
mengakumulasikan berbagai macam pengetahuan. ${ }^{5}$ Kemudian lebih lanjut ia menyatakan sinergi adalah suatu gagasan baru, yang terbentuk dari berbagai macam gagasan yang diajukan oleh banyak pihak hingga menghasilkan suatu gagasan baru, yang dilandasi oleh pola pikir atau konsep yang baru. Timbulnya gagasan baru dan kepuasan yang mengikutinya tidak akan dapat diperoleh tanpa kerjasama efektif dari semua pihak. ${ }^{6}$

Pengertian pendidikan Islam dengan seluruh totalitasnya dalam konteks Islam, sangat inheren dengan konotasi istilah tarbiyah, ta'lim, dan ta'dib yang harus dipahami secara bersama-sama yaitu pendidikan. Memahami istilah tersebut para pakar pendidikan Islam berpendapat, antara lain, Abd. Rahman Getteng berpendapat bahwa pendidikan Islam adalah usaha untuk membimbing dan mengembangkan potensi manusia baik jasmani maupun rohani agar tujuan kehadiranya didunia sebagai hamba Allah dan khalifah tercapai dengan baik. ${ }^{7}$ Hal ini terdapat kesesuaian dengan pendapat Hasan Langgulung yang merumuskan pendidikan Islam yakni adanya penyiapan generasi muda untuk mengisi peranan, memindahkan pengetahuan dan nilai-nilai Islam yang diselaraskan dengan fungsi manusia untuk beramal dan memetik hasilnya di akhirat. ${ }^{8}$ Sedangkan Azyumardi Azra lebih cenderung kepada pembentukan pribadi-pribadi yang didasarkan dari nilai agama. Sebagaimana ia mengemukakan bahwa "pendidikan Islam adalah usaha membentuk pribadi-pribadi yang bernafaskan ajaran-ajaran Islam, sehingga pribadi-pribadi yang terbentuk itu tidak lepas dari nilai-nilai agama". 9

Dari konsep di atas bahwa sinergisitas pendidikan Islam adalah usaha membangun dan memastikan hubungan kerjasama internal yang produktif serta kemitraan yang harmonis dengan pelaku pendidikan, untuk menghasilkan karya dan usaha yang bermanfaat dan berkualitas terhadap pelaksanaan pendidikan Islam.Haidar Putra Daulay mengungkapkan bahwa pendidikan Islam dalam berbagai jenjang dan jenisnya telah dibangun berdasarkan semangat umat Islam antara pemerintah, masyarakat dan keluarga untuk kepentingan pendidikan bagi anakanaknya. ${ }^{10}$ Membangun sinergisitas pendidikan Islam berarti membina kerjasama

\footnotetext{
${ }^{5}$ Ismail Solihin, Manajemen Strategik,(Jakarta, Erlangga, 2012), 65

${ }^{6}$ Ibid.

${ }^{7}$ Abd. Rahman Getteng, Pendidikan Islam Dan Pembangunan, (Ujung Pandang: Yayasan Ahkam; 1997), 25

${ }^{8}$ Hasan Langgulung, Beberapa Pemikiran Tentang Pendidikan Islam, (Bandung: Al-Ma'rif; 1980), 94

${ }^{9}$ Azyumardi Azra, Esei-Esei Intelektual Muslim \& Pendidikan Islam, (Jakarta: Logos Wacana Ilmu; 1998), 6

${ }^{10}$ Haidah Putra Daulay: Dalam Sistem Pendidikan Nasional Di Indonesia, (Jakarta, Kencana Prenada Media Group, 2007), 51
} 
antara pemangku kepentingan pendidikan Islam antara keluarga, sekolah dan masyarakat, hal ini lebih dikenal dengan sinergisitas tri pusat pendidikan dalam mewujudkan generasi yang memiliki pengatahuan dan karakter berdasarkan nilainilai ajaran Islam. ${ }^{11}$ Pendidikan Islam di Indonesia dapat dijumpai di berbagai lembaga-lembaga yang berbasis Islami mulai dari tingkat rendah sampai tingkat yang paling tinggi, seperti:pondok pesantren, madrasah dari berbagai jenjang (MI, MTs, MA), Perguruan Tinggi Keagamaan Islam (UIN, IAIN, STAIN), merupakan lembaga formal pendidikan Islam. Namun pendidikan Islam juga bisa diperoleh di lembagalembaga umum misalnya SD, SMP, SMA, SMK, dan lain-lain, sebagai salah satu mata pelajaran. Dan pada pendidikan Islam non-formal antara lainPendidikan dalam keluarga, majelis taklim, TPQ dan lain-lain. Lembaga pendidikan Islam tersebut memiliki kurikulum dan metode mengajar yang berpusat pada penanaman terhadap nilai-nilai ajaran Islam.

\section{Sinergisitas Pendidikan Islam Formal Dan Non-Formal.}

A Malik Fajar secara khsusus menjelaskan bahwa sinergisitas pendidikan Islam dibuat agar pranata pendidikan tidak berjalan sendiri-sendiri untuk dan dapat membentuk sinergi positif memadukan kegiatan yang berbentuk formal dan nonformal dengan sasaran dan tujuan mendidik umat Islam baik pada sekolah/madrasah, pondok pesantren, keluarga, majelis taklim dan perguruan tinggi Islam untuk mendukung proses pembangunan bangsa menjadi satu kesatuan yang utuh pada tingkat pelaksanaannya. ${ }^{12}$

Untuk menyikapi pendapat di atas, dalam membentuk sinergitas pendidikan Islam, pelaksanaan pendidikan Islam dapat dilihat dari dan dalam bentuk sinergisitas kerjasama antar lembaga pendidikan Islam dan sinergisitas berorientasi pada mutu dan nilai pendidikan. Integrated, dan sinergi yang dimaksudkaan adalah memberikan pengaruh-pengaruh dan pengembangan kepada pelaksanaan pendidikan Islam untuk masa depan anak, baik antara lembaga pendidikan, keluarga dan masyarakat harus saling membutuhkan dalam proses penddikan anak.Akan tetapi, yang terjadi justru sebaliknya. Karena alasan sibuk, tidak jarang keluarga yang merasa cukup menyerahkan pendidikan kepada sekolah. Padahal, disadari bahwa interaksi guru murid di sekolah amatlah terbatas dari segi waktu dan kesempatan.Di antara faktor efektif dalam pembentukan kepribadian intelektual anak, rohani, dan fisiknya adalah mengadakan kerjasama atau sinergitas yang baik antara rumah, sekolah, dan

\footnotetext{
${ }^{11}$ Mislaini, Khazanah Ilmu PendidikanIslam, (Padang, Hayfa Press, 2016), 305

${ }^{12}$ A. Malik Fajar, Holistik Pemikiran Pendidikan, (Jakarta, Raja Grafindo Persada, 2005), 108
} 
masyarakat.Sebagaimana yang kita ketahui bahwa rumah memiliki peranan tanggung jawab nomor satu dalam mendidik anak dari segi fisiknya.

Untuk mengantasisipasi pernyataan di atas, pola hubungan sinergisitas pada pengembangan kultur lembaga pendidikan Islammenjadi perlu dalam manajemen lembaga pendidikan dengan semangat pembentukan karakter peserta didik sebagaimana kebijakan pendidikan karakter pada sistem pendidikan nasional pada saat ini. Integrasi dimaksud diupayakan agar setiap pengelola layanan jasa pendidikan pada sekolah di lingkungan pendidikan misalnya juga memiliki karakter dan budaya yang baik dalam setiap tindakan manajemen yang dilakukannya. Selain dapat menjadi cermin atau tauladan bagi peserta didik adalah juga menjadikan akhlak sebagai ruh atau jiwa yang melekat pada setiap tindakan pengelolaan sekolah.

\section{Sinergisitas dalam bentuk kerjasama lembaga pendidikan Islam.}

Secara harfiyah, kerja sama dapat diartikan bekerja sama secara bersamasama. Kerja sama merupakan terjemahan dari kata working to-gether (bekerja bersama-sama), ${ }^{13}$ dan al-ta'awwum yang secara harfiyah berarti menolong, bahumembahu, isi-mengisi, dukung mendukung, menerima dan memberi. ${ }^{14}$ Kata kerjasama juga memiliki makna yang sama dengan kata kemitraan dan kolaborasi yakni sebuah bentuk dari interaksi social yang bersifat asosiatif yaitu pekerjaan dilakukan oleh dua orang atau lebih dimana mereka memiliki pandangan yang sama untuk mencapai tujuan tertentu. Saling membantu dalam membangun kebaikan termasuk dalam membina pendidikan telah terwariskan oleh kebiasaan para ulama dalam menyebarkan ilmu pengetahuan.Hal ini sebagaimana diisyaratkan dalam AlQur'an.Dalam al-Qur'an surah al-Maidah ayat 2 Allah SWT berfirman:

"Hai orang-orang yang beriman, janganlah kamu melanggar syi'ar-syi'ar Allah, dan jangan melanggar kehormatan bulan-bulan haram, jangan (mengganggu) binatang-binatang had-ya, dan binatang-binatang qalaa-id, dan jangan (pula) mengganggu orang-orang yang mengunjungi Baitullah sedang mereka mencari kurnia dan keredhaan dari Tuhannya dan apabila kamu telah menyelesaikan ibadah haji, Maka bolehlah berburu. dan janganlah sekali-kali kebencian(mu) kepada sesuatu kaum karena mereka menghalang-halangi kamu dari Masjidilharam, mendorongmu berbuat aniaya (kepada mereka). dan tolong-menolonglah kamu dalam (mengerjakan) kebajikan dan takwa, dan jangan tolong-menolong dalam berbuat dosa dan pelanggaran. dan bertakwalah kamu kepada Allah, Sesungguhnya Allah Amat berat siksa-Nya”.

At-Thobary memahami makna umum ayat ini berdasarkan redaksinya tolong menolonglah kalian bahwa Allah swt memerintahkan semua hamba-Nya agar

${ }^{13}$ John M. Echols dan Hassan Shadily, Kamus Inggris-Indonesia (Cet. 29; Jakarta: PT. Gramedia, 2007), 372.

${ }^{14}$ Ahmad Warson Munawwar...,432 
senantiasa tolong menolong dalam melakukan kebaikan-kebaikan yang termasuk kategori Al-Birr dan mencegah dari terjadinya kemungkaran sebagai realisasi dari takwa.Sebaliknya Allah swt melarang mendukung segala jenis perbuatan batil yang melahirkan dosa dan permusuhan. ${ }^{15}$ Dalam pendidikan Islam merupakan salah satu fitrah, kemutlakan pendidikan Islam sebagaimana makna dan kebutuhan kemitraan dan kolaborasi dalam dunia kehidupan manusia sebagai mahluk sosial. Secara detail Jawwad memberikan rambu-rambu bahwa kemitraan dan kolaborasi harus mampu memberikan fasilitasi yang nyata bagi pelakunya untuk memperoleh kemanfaatan yang besar dalam merealisasikan visi, misi, dan tujuannya. ${ }^{16}$

Untuk mencapai tujuan kerja sama dalam lembaga pendidikan, khsususnya lembaga pendidikan Islam, Abuddin Nata mengemukakan paling tidak dapat memberikan keuntungan dan manfaatnya, antara lain:

1. Dapat menjaring peserta didik atau mahasiswa yang lebih luas untuk memasuki lembaga pendidikan dan program-program yang ditawarkan.

2. Dapat melakukan penghematan waktu, tenaga dan biaya dalam penyelenggaraan pendidikan.

3. Dapat digunakan untuk membantu citra positif lembaga, sehingga lebih dikenal dan dipercaya oleh masyarakat.

4. Dapat digunakan untuk meningkatkan jaringan pemasaran jasa pendidikan kepada masyarakat. $^{17}$

Dalam hal, peningkatan kerja samatertuang secara jelas dalam lampiran Permendiknas Nomor 19 Tahun 2007 tentang Standar Pengelolaan Pendidikan yang menyatakan bahwa setiap sekolah/lembaga pendidikan menjalin kemitraan dengan lembaga lain yang relevan, berkaitan dengan input, proses, output, dan pemanfaatan lulusan. Kemitraan sekolah dapat dilakukan dengan lembaga pemerintah maupun non-pemerintah seperti perguruan tinggi, sekolah yang setara, serta dunia usaha dan dunia industri di lingkungannya.Artinya bahwa, lembaga pendidikan Islam harus mengembangkan kerjasama dan kemitraan dengan masyarakat, dunia industri, dunia usaha, alumni dan satuan pendidikan lainnya di dalam maupun luar negeri.Sebagai satu indikator mutu operasional lembaga adalah dengan melaksanakan kegiatan tukar pengalaman. Puncak dari keberhasilan itu ditandai dengan pelaksanaan kerja sama kemitraan dengan lembaga pendidikan di negara-negara yang berkeunggulan dalam bidang pendidikan yang terkait dengan peningkatan mutu lulusan sehingga

${ }^{15}$ Abi Ja'far Muhammad Bin Jarir At-Thobari, Tafsir At-Thobari, (Beirut, Darul Kutb Ilmiyah, 405

${ }^{16}$ Muhammad Abdul Jawwad, Menjadi Manajer Sukses, (Jakarta, Gema Insani Press, 2000), 371

\footnotetext{
${ }^{17}$ Abuddin Nata, Ilmu Pendidikan Islam, (Jakarta, Kencana, 2010), 280
} 
pendidikan Islam menghasilkan mutu yang setara dengan sekolah unggul lainnya.Kerjasama dalam pendidikan Islam adalah upaya menjalin kemitraan pada semua lembaga-lembaga pendidikan Islam untuk menghasilkan mutu dan hasil pendidikan yang berkualitas antara lain:

a. Kerja sama dalam program pembinaan antar lembaga pendidikan Islam

b. Kerja sama pada bidang pengelolaan pendidikan Islam

c. Kerjasama program penciptaan iklim pendidikan yang kondusif.

d. Kerjasama program peningkatan akses pembelajaran pendididkan Islam

e. kerjasama program pengembangan SDM dalam pendidikan Islam. ${ }^{18}$

Agar tercapainya tujuan kerja sama di atas, Abuddin Nata lebih lanjut menyampaikan untuk meraih prestasi tidaklah semudah mempertahankan dan meningkatkannya. ${ }^{19}$ Untuk itu, lembaga pendidikan Islam diharapkan agar tetap stabil dalam menjalankan fungsi dan tujuannya, baik dalam hal manajemen maupun muatan yang diajarkan di dalamnya. Agar tetap berperan strategis dalam pendidikan nasional, ada beberapa hal yang perlu dipertahankan dan ditingkatkan oleh lembaga pendidikan Islam sebagai berikut: Pertama, Lembaga Pendidikan Islam harus mampu mempertahankan dan meningkatkan ciri atau karakter keislaman di dalamnya. Nuansa dan nilai-nilai islami yang terpraktekkan dalam kehidupan sehari-hari para siswanya adalah hal yang diutamakan daripada hanya sekadar pengetahuan keislaman sebatas teoritis belaka. Kedua, Lembaga Pendidikan Islam harus mampu mempertahankan dan meningkatkan ciri unggulan yang melekat pada dirinya, apabila dibandingkan dengan lembaga pendidikan umum misalnya dalam hal keilmuan (bimbingan plus IPTEK, laboratorium alam, bimbingan intensif bekerjasama dengan bimbel terkemuka), dalam hal keterampilan (komputer, beladiri, seni islami, teknologi tepat guna, usaha kecil, kepanduan, dan lain-lain), atau dalam hal interaksi sosial.

Ketiga, Lembaga pendidikan Islam harus mampu meningkatkan kemampuan dalam pola manajeman dan muatan kurikulum, siswa baru yang diseleksi ketat, staf pengajar dan karyawan yang berkualitas, kendali kualitas (quality control) terhadap lulusan, serta sarana dan prasarana yang lengkap. Keempat, Lembaga pendidikan Islam harus gencar untuk menampilkan diri pada setiap kesempatan yang ada agar semakin dikenal dan dipercaya oleh orangtua dalam menitipkan masa depan anakanaknya. Peluang-peluang besar bagi lembaga pendidikan Islam untuk menjadi

\footnotetext{
${ }^{18}$ Hasbullah, Kapita Selekta Pendidikan Islam, (Jakarta, RajaGrafindo Persada, 1999), h. 61

${ }^{19}$ Abuddin Nata, Sejarah Pendidikan Islam Pada Periode Klasik dan Pertengahan, (Jakarta: PT. Raja Grafindo Persada, 2004), 74
} 
lembaga pendidikan teratas di Indonesia adalah keniscayaan, setidaknya peluang itu dapat dilihat dari jumlah penduduk di Indonesia yang menganut agama Islam.

\section{Sinergisitas Pendidikan Madrasah, Keluarga dan Masyarakat.}

Secara faktual, pendidikan melibatkan tiga unsur pelaksana, yakni keluarga, madrasah/sekolah dan masyarakat. ${ }^{20}$ Madrasah berfungsi untuk mengintroduksikan kurikulum pendidikan secara formal sesuai dengan jenjang yang ada. keluargamemberikan dukungan pendidikan awal di luar sekolah yang dapat dimanfaatkan untuk mendukung pendidikan formal. Sikap disiplin, kemandirian, kepemimpinan dan tanggung jawab dapat diciptakan dalam keluarga. Sedangkan masyarakat merupakan pusat interaksi keislaman untuk mendukung pendidikan formal. Di masyarakat, akan terbina dengan akhlak dan tingkah laku yang baik, jika ketiganya disinergikan, diharapkan akan tercipta budaya sekolah yang ideal. ${ }^{21}$

Selanjutnya, dibuka lebar ruang interaksi dengan keluarga dan masyarakat agar dapat berperan optimal dalam menunjang proses pendidikan. Sinergi pengaruh positif dari faktor pendidikan madrasah-keluarga-masyarakat inilah yang akan menjadikan pribadi anak didik yang utuh sesuai dengan kehendak Islam.Pihak keluarga dan sekolah dituntut untuk melakukan kerjasama atau sinergitas dalam membina pendidikan Islam.Dalam praktiknya, madrasahdapat menata hubungan harmonis dengan wali muridnya.Lebih jauh lagi, sekolah mampu mengetahui identitas wali muridnya, mulai dari alamat, nomor telepon, suasana keluarga, dan metode yang mereka pakai untuk mendidik murid di rumah. Hubungan kemitraan antara madrasah dan keluarga akan membentuk pendidikan yang sempurna bagi muridnya karena apa yang tidak tuntas di madrasah, dapat di tuntaskan di rumah, dan sebaliknya, apa yang tidak tuntas di rumah akan di tuntaskan di madrasah. Atau bisa jadi juga, kedua bela pihak saling mengoreksi dalam membina anak-anak didiknya sehingga anak-anak terhindar dari kontradiksi pendidikan madrasah dan pendidikan rumah.

Pada dasarnya madrasah harus merupakan suatu lembaga yang membantu bagi tercapainya cita-cita keluarga dan masyarakat, khususnya masyarakat Islam, dalam bidang pengajaran yang tidak dapat secara sempurna dilakukan dalam rumah dan masjid.Bagi umat Islam, lembaga pendidikan yang dapat memenuhi harapan ialah lembaga pendidikan Islam, artinya bukan sekedar lembaga yang di dalamnya diajarkan pelajaran agama Islam, melainkan suatu lembaga pendidikan yang secara

\footnotetext{
${ }^{20}$ Ramayulis, Ilmu Pendidikan Islam, (Jakarta, Kalam Mulia, 199), h. 279

${ }^{21}$ Rehani, Berawal Dari Keluarga: Revolusi Belajar Cara Al-Qur'an, (Jakarta, Hikmah, 2003), h. 15
} 
keseluruhannya bernapaskan Islam.Hal itu hanya mungkin terwujud jika terdapat keserasian antara rumah dan madrasah dalam pandangan keagamaan. ${ }^{22}$

Anak-anak dari keluarga Muslim yang bersekolah sesunggunya secara serempak hidup dalam tiga lingkungan, yaitu keluarga, masjid, dan madrasah.Ketiga unsur itu harus serasi, saling mengisi dan bersinergi dalam membentuk kepribadian anak didik.Namun, menurut Abdullah Nashih 'Ulwan sinergi lembaga pendidikan ini tidak akan bisa maksimal jika belum memenuhi dua syarat asasi berikut ini.Pertama, tidak adanya dualisme atau paradoks antara pengarahan yang diberikan rumah dan madarsah.Kedua, kerjasama yang terjalin harus bertujuan untuk mengadakan integritas dan keseimbangan dalam membentuk kepribadian anak yang Islami. ${ }^{23}$ Jika sinergitas atau kerjasama tersebut sudah mencakup dua hal tersebut, maka anak akan memiliki kepribadian yang sempurna, mencakup rohani, jasmani, intelektual, dan mentalnya. Bahkan, ia menjadi manusia yang seimbang dan sempurna yang disenangi semua orang dan menjadi teladan yang baik. Sehingga dapat dimengerti betapa pentingnya kerja sama atau sinergitas antara rumah dan madrasah. Kerja sama itu hanya tercapai, apabilah kedua belah pihak saling mengenal. Orang tua harus mengenal anaknya, sekolah dan guru.

\section{Model Sinergisitas Pendidikan Islam Sebagai Alternatif Pendidikan Masa Kini dan Mendatang.}

Seperti telah dijelaskan di atas, sesuatu yang mafhum bahwa membangun pendidikan yang baik dan berkualitas serta dibutuhkan oleh umat Islam khususnya pendidikan Islam dengan merancang model dan cara yang menunjang adanya peningkatan kualitas tersebut. A Malik Fajar, secara khusus menjelaskan bahwa pendidikan masa depan perlu adanya model baru pengembangan pendidikan Islam sebagai praksis pembangunan bangsa baik pada tahap konseptual, perancangan model dan desain, sampai pada tahapan perintisan dan pengembangan. ${ }^{24}$ Model dimaksud tentu mampu untuk menjawab tuntutan perubahan di segala aspek pendidikan. Model yang akan menjawab tantangan ke depan sepertinya tidak bisa ditawar-tawar lagi, perkembangan masyarakat dunia dari waktu ke-waktu terus mendorong kearah perubahan, pendidikan sebagai bagian dari kebutuhan umat Islam,mau tidak mau dipaksa untuk ikut dalam perubahan itu. Sekarang ini arus globlisasi tidak terhindarkan lagi, era informasi telah merubah wajah dunia menjadi semakin

\footnotetext{
${ }^{22}$ Zakiah Daradjat, dkk, Ilmu Pendidikan Islam,(Jakarta : Bumi Aksara, 1992),40
}

${ }^{23}$ Abdullāh Naşih 'Ulwān, Tarbiyah al-Awlād fì al-Islām, Juz 2 (Cet. 21; Jeddah: Dār alSalām, 1412 H./1992 M.), 635.

${ }^{24}$ A. Malik Fajar, Holistik Pemikiran Pendidikan, (Jakarta, Raja Grafindo Persada, 2005), 110 
indah.Era ini ditandai dengan ciri-ciri seperti menguasai dan mampu mendayagunakan arus informasi, bersaing terus menerus belajar, dan menguasai kemampuan menggunakan berbagai teknologi.

Kondisi ini selanjutnya akan mempengaruhi dunia pendidikan, yang pada giliranya menjadi tantangan yang harus dijawab oleh dunia pendidikan khususnya Lembaga Pendidikan Islam. Oleh karena itu melalui slide ini mencoba mendeskripsikan tentang strategi pengembangan Pendidikan Islam dalam upaya mengantisipasi perkembangan ilmu pengetahuan dan teknologi dewasa ini dan dimasa-masa mendatang.Sebagai konsep yang masih paradigmatik, dalam membangun sinergisitas pendidikan Islam adalah sebagai berikut:

\section{Sinergisitas Pendidikan Islam Dalam Bentuk Koordinasi-Komunikatif}

Diakui atau tidak, sistem pendidikan yang berjalan di Indonesia saat ini memang adalah sistem pendidikan yang sekular-materialistik. Bila disebut bahwa sistem pendidikan nasional masih mewarisi sistem pendidikan kolonial, maka watak sekuler-materialistik inilah yang paling utama, yang tampak jelas pada hilangnya nilai-nilai transedental (ilahiyah) pada semua proses pendidikan, mulai dari peletakan filosofi pendidikan, penyusunan kurikulum dan materi ajar, kualifikasi pengajar, proses belajar mengajar hingga budaya sekolah/kampus sebagai hidden curiculum, yang sebenarnya berperanan sangat penting dalam penanaman nilai-nilai.Menatap masa depan, dunia pendidikan pesantren menghadapi tantangan yang relatif semakin kompeleks. Sebagai institusi pendidikan Islam yang khas lokal, pesantren memiliki sejumlah keunggulan, sekaligus juga berbagai persoalan dan kelemahan yang menggurita di dalamnya. Sehingga hal ini membutuhkan penyikapan yang arif dan terbuka, terlebih dalam konteks mengadaptasikan diri dengan sistem dan budaya global yang datang dari luar.

Resonansi arus reformasi pendidikan nasional yang kencang dan ber-pengaruh terhadap pelbagai lini kehidupan, memang tidak menggoyahkan sistem nilai pendidikan pesantren. Bahkan dalam menghadapi goncangan itu, pesantren bukan hanya mampu bertahan, melainkan juga mampu meng-emban formulasi sitem pendidikan se-cara sistmatis, rasional, obyektif dan islami. Dari sini kemudian diharapkan mampu menyentuh sisi perencanaan, proses, isi, organisasi, kelembagaan, jenjang, manajemen dan seterusnya.Proses pembentukan sistem pendidikan pesantren dan madrasah pada hakikatnya bukan hanya melibatkan pengelola, namun di dalamnya mengandaikan peran aktif atau keterlibatan masyarakat dan kebijakan pemerintah. Dengan kesadaran seperti ini, ke depan peningkatan hubungan partisipatif antara pihak pengelola pendidikan dengan stakeholders dan pemerintah lebih dilakukan secara intens dan berkesinambungan. Dengan begitu, diharapkan akan 
memperkuat surviva-litas pesantren di era globalisasi. Hubungan emosional antara pengelola pendi-dikan pesantren dengan stakeholders dan rasa memiliki mereka tehadap lembaga akan semakin kuat, manakala adanya keterbukaan pihak pesantren dalam menerima berbagai masukan dan setiap keterlibatan masyarakat, dari mulai perencanaan, pelaksanaan, evaluasi, bahkan dalam pelaksanaan program peningkatan mutu pen-didikannya.Terdapat kesan yang sangat kuat bahwa pengembangan ilmuilmu kehidupan (iptek) dilakukan oleh Depdiknas dan dipandang sebagai tidak berhubungan dengan agama. Sementara, pembentukan karakter siswa yang merupakan bagian terpenting dari proses pendidikan di sini justru kurang tergarap secara serius. Agama ditempatkan sekadar sebagai salah satu aspek yang perannya sangat minimal, bukan menjadi landasan dari seluruh aspek. ${ }^{25}$

Pada konsep koordinasi-komunikasi pendidikan yang integral melibatkan tiga unsur pelaksana: yaitu keluarga, sekolah dan masyarakat. Membangun komunikasi menggambarkan bahwa pendidikan Islam, di mana ketiga unsur pelaksana tersebut berjalan secara sinergis.sinergisitas koordonasi-komunikasi sebenarnya sama dengan menggagas suatu sistem pendidikan alternative yang bersendikan pada dua cara yang lebih bersifat strategis dan fungsional, yakni: Pertama, membangun komunikasi antar lembaga pendidikan unggulan (sekolah, madrasah dan pondok pesantren) dimana semua komponen berbasis paradigma Islam, yaitu: (1) kurikulum yang paradigmatik, (2) guru/tenaga pendidik yang profesional, amanah dan kafa'ah, (3) proses belajar mengajar secara Islami, dan (4) lingkungan dan budaya sekolah yang kondusif bagi pencapaian tujuan pendidikan secara optimal. ${ }^{26}$ Dengan melakukan optimasi proses belajar mengajar serta melakukan upaya meminimasi pengaruh-pengaruh negatif yang ada, dan pada saat yang sama meningkatkan pengaruh positif pada anak didik, diharapkan pengaruh yang diberikan pada pribadi anak didik adalah positif sejalan dengan arahan Islam.

Kedua, membuka lebar ruang interaksi dengan sekolah dan pesantren agar keduanya dapat berperan optimal dalam menunjang proses pendidikan Islam. Sinergi pengaruh positif dari faktor pendidikan tersebut yang akan membuat pribadi anak didik terbentuk secara utuh sesuai dengan kehendak Islam.Misalkan ketika peserta didik di sekolah terpengaruh dengan moral dan karakter yang tidak baik (narkoba, miras, perkelahian, dll), sekolah menjalin komunikasi dengan pesentren agar peserta

${ }^{25}$ H.M. Amin Haedari, Pendidikan Agama Islam Di Indonesia: Gagasan Dan Realitas, (Jakarta, Puslitbang Kemenag RI, 2010), 2

${ }^{26}$ Muhaimin, Pemikiran Dan Aktualisasi Pengembangan Pendidikan Islam, (Jakarta, Rajawai Press, 2012), 23 
didik tersebut dimasukkan ke dalam pesantren untuk dibina iman, ibadah dan diperbaiki moral dan akhlaknya.

Oleh karena itu, penyelesaian problem pendidikan yang mendasar harus dilakukan pula secara fundamental, dan itu hanya dapat diwujudkan dengan melakukan perbaikan secara menyeluruh yang diawali dari perubahan paradigma pendidikan sekuler menjadi paradigma Islam. Sementara pada tataran derivatnya, kelemahan ketiga faktor di atas diselesaikan dengan cara memperbaiki strategi fungsionalnya sesuai dengan arahan Islam. ${ }^{27}$ Secara paradigmatik, pendidikan harus dikembalikan pada asas aqidah Islam yang bakal menjadi dasar penentuan arah dan tujuan pendidikan sebagaimana yang menjadi visi, masi pada pondok pesantren, penyusunan kurikulum dan standar nilai ilmu pengetahuan serta proses belajar mengajar, termasuk penentuan kualifikasi guru serta budaya sekolah yang akan dikembangkan pada madrasah. Sekalipun pengaruhnya tidak sebesar unsur pendidikan yang lain, penyediaan sarana dan prasarana juga harus mengacu pada asas di atas.Lahirnya penyelenggaraan pendidikan yang terpadu merupakan upaya membangun sinergisitas terhadap proses pelaksanaan pendidikan Islam yang sesungguhnya untuk diterapkan dalam lembaga pendidikan Islam, antara lain:

\section{a. Pendidikan Umum Berbasis Pesantren}

Sekolah Berbasis Pesantren atau yang disebut dengan (SBP) secara nasional mulai dideklarasikan tahun 2008, dengan tujuan mengintegrasikan kebenaran nash (Al-Quran dan Hadits) dengan sains (ilmu pengetahuan dan teknologi) melalui pengembangan tiga dimensi pendidikan unggul. Hal ini sbagai upaya Pemilikanlandasanmoralitaskeagamaanyangkuat,penguasaanilmu pengetahuan dan teknologi, serta memiliki dan menguasai bentuk-bentuk keterampilan-keterampilan bekerja yang akan menunjang keilmuan. ${ }^{28}$ Pesantren yang menyelenggarakan Sekolah Berbasis Pesantren telah melakukan perubahan karena kebutuhan pesantren untuk menanggapi arus globalisasi, yang berawal dari penghayatan dan pemahaman keagamaan kiyai, kemudian diaktualisasikan sebagai amal saleh. Dinamika pesantren semakin adaptif dengan perkembangan zaman dengan menyelenggarakan sekolah umum berbasis pesantren, menjadikan pesantren memiliki peluang sebagai lembaga pendidikan Islam yang akan menciptakan manusia seutuhnya, dan membentuk

${ }^{27}$ Muhaimin, Nuansa Baru Pendidikan Islam: Mengurai Belang kusut Dunia Pendidikan, (Jakarta, Radja Grafindo Persada, 2006), 107

${ }^{28}$ Kementerian Pendidikan dan Kebudayaan RI, Direktorat Jenderal Pendidikan Dasar dan Menengah, Direktorat Pembinaan SMP, Laporan Monitoring dan Evaluasi Program Sekolah Berbasis Pesantren (Jakarta: Kemendikdasmen, 2016), 4. 
masyarakat madani yang bercirikan masyarakat religius, demokratis, egalitarian, toleran, berkeadilan, dan berilmu. ${ }^{29}$

Sekolah berbasis pesantren mengintegrasikan kebenaran nash (Al-Quran dan Hadits) dengan sains (ilmu pengetahuan dan teknologi) melalui pengembangan tiga dimensi pendidikan unggul. Pemilikan landasan moralitas keagamaan yang kuat, penguasaan ilmu pengetahuan dan teknologi, serta memiliki dan menguasai bentukbentuk keterampilan-keterampilan bekerja yang akan menunjangkehidupannya setelah selesai mengikuti pendidikan. Sekolah Berbasis Pesantren (SBP) merupakan model pendidikan yang mampu mengembangkan multiple intelligence (kecerdasan majemuk), spiritual-keagamaan, kecakapan hidup, dan penguatan karakter kebangsaaan. Sekolah Berbasis Pesantren (SBP) merupakan model sekolah yang mengintegrasikan keunggulan sistem pendidikan yang diselenggarakan di sekolah dan keunggulan sistem pendidikan di pesantren.Pada tataran implementasinya, SBP merupakan model pendidikan unggulan yang mengintegrasikan pelaksanaan sistem persekolahan yang menitikberatkan pada pengembangan kemampuan sains dan keterampilan dengan pelaksanaan sistem pesantren yang menitikberatkan pada pengembangan sikap dan praktik keagamaan, peningkatan moralitas dan kemandirian dalam hidup.Perubahan sosial ini mengacu pada perubahan sistem sosial dan budaya yang memadukan sistem pendidikan sekolah dan sistem pendidikan pesantren, sehingga meluluskan ilmuwan yang agamawan.Sekolah berbasis pesantren memadukan sistem pendidikan di sekolah formal dan di pondok pesantren, ini dikembangkan setelah melihat danmengamati secara seksama mutu pendidikan yang dilahirkan oleh masing-masing sistem. ${ }^{30}$

\section{b. Pendidikan Madrasah Berbasis Pesantren}

Sistem pengelolaan madrasah di pesantren harus diarahkan menuju terciptanya out-comes dengan tingkat pencapaian yang memadai, baik dari sisi kognitif, afektif, maupun psikomotor, dengan tekanan pembinaan moral sebagai ciri khasnya. Substansi perubahan kebijakan madrasah dan sekolah yang mengkhususkan konsentrasinya pada kajian agama (tafaqquh fi ad-dîn) menjadi sekolah umum dengan karakter khusus agama Islam, adalah dalam rangka mengarahkan, membimbing, membina, dan melahirkan out-put pendidikan madrasah yang qualified, sanggup mengemban pandangan hidup (kognitif), sikap hidup (afektif) dan

\footnotetext{
${ }^{29}$ Haidah Putra Daulay...,36.

${ }^{30} \mathrm{Ibid}$.
} 
vocational(psikomotor) dalam konteks ke-Islaman, sehingga tercipta manusia Indonesia paripurna. ${ }^{31}$

Pada prinsipnya, proses kependidikan termasuk di dalamnya pesantren dan madrasah, dalam praktek penyelenggaraannya memiliki tiga dimesi. Ketiga proses ini harus berjalan secara simultan, yaitu sebagai proses belajar, proses ekonomi, dan sebagai proses budaya. Sebagai proses belajar, pendidikan harus mampu memproduksi kualitas individu dan masyarakat yang relijius, dan secara personal diharapkan memiliki integritas, kecerdasan dan keterampilan (vocational) serta keimanan. Secara ekonomi, pendidikan merupakan investasi jangka panjang, terutama dari sektor penyiapan dan peningkatan kualitas SDM. Sedangkan dalam kapasitasnya sebagai proses sosial budaya, pendidikan menjalankan fungsi transmisi dan pemeliharaan nilai-nilai budaya dan tradisi. Dengan demikian, suatu sistem budaya diharapkan akan terus mempunyai sustainibilitas atau kesinambungannya dari satu generasi ke generasi lainnya. ${ }^{32}$ Sementara itu, proses pendidikan Islam yang efektif mencerminkan sandaran filosofis yang humanis, membawa misi akademis, nilai-nilai, dan keluhuran moral Islami. Di mana, semua komponen penyelenggaraan pendidikan di pesantren ataupun madrasah mempunyai relasi tanggung jawab terhadap keberlanjutan penyelenggaraan pendidikan Islam. Lebih dari itu, bagaimana menjadikan nilai-nilai tersebut mampu menjiwai proses penyelenggaraan pendidikan, mulai dari aspek proses, lembaga, isi, sampai pada manajerialnya. ${ }^{33}$

Pendididkan madrasah yang diselenggarakan pada pondok pesantren dan atau madrasah memiliki asrama seperti pembinaan pada pondok pesantren, memiliki tujuan agar keilmuan pada pesantren dapat diberikan kepada peserta didik yang belajar pada madrasah. Untuk menuju terciptanya pendidikan terpadu di lingkungan pesantren dan madrasah, sebelumnya visi dan misi pendidikan harus berpijak pada filosofi dan nilai dasar pesantren (madrasah) yang relevan dengan cita-cita dan ketentuan prinsip-prinsip pendidikan Islam. Di mana, hal ini didasarkan pada ajaran Islam, latar belakang historis, dan kondisi obyektif masyarakat muslim dalam bingkai budaya multikultural bangsa Indonesia. Selanjutnya, pendidikan pesantren dan madrasah hendaknya diletakkan dalam kerangka tujuan (ghayah) hidup menurut pandangan Islam, yaitu compatible dengan tujuan hidup manusia menurut pandangan Islam. Sebab, pendidikan hanyalah instrumen yang ditempuh agar tujuan hidup tercapai. Oleh karena itu, perumusan pendidikan pesantren dan madrasah, identik

${ }^{31}$ Azyumardi Azra, Pendidikan Islam: Tradisi Dan Modernisasi Menuju Milenium Baru, (Jakarta, Logos, 1999), 69

${ }^{32} \mathrm{Ibid}$, h. 70

${ }^{33}$ Mujammil Qamar, Menggagas Pendidikan Islam, (Bandung, Remaja RosdaKarya, 2014), 100 
dengan tujuan pendidikan Islam sendiri. Dalam formulasinya harus memiliki keterpaduan, terutama berorientasi pada hakikat pendidikan.

Unsur-unsur penting dalam kaitannya dengan integrasi madrasah dan pesantren, antara lain menyangkut beberapa prinsip berikut, yaitu: ${ }^{34}$ masalah integrasi keilmuan, integrasi kurikulum, integrasi sarana, integrasi manajemen antara lain.Pertama, integrasi keilmuan yang memadukan ilmu agama dengan ilmu umum. Kedua, masalah kurikulum dalam konteks keterpaduan sistem pendidikan Islam pada pondok pesantren dan madrasah, Isi atau materi kurikulum pendidikan modern terangkum dalam tiga ranah, yaitu ilmu pengetahuan (kognitif) sikap atau nilai-nilai (afketif) dan keterampilan (psiko-motorik). Sementara dalam kon1teks pendidikan Islam, di samping ketiga ranah di atas, yang dianggap menjadi inti kurikulum dalam konsepsi Islam adalah bertumpu pada nilai keimanan dan moral. Sehingga, isi kurikulum pendidikan modern, setelah diadaptasikan dengan konsepsi Islam, akan menjadikan kurikulum mendapatkan spirit atau semangat etik-transendental, sehingga pada saat yang bersamaan ada semacam proses integrasi antara ilmu yang berorientasi duniawi dengan ilmu-ilmu yang berorientasi ukhrawi. Sehingga secara psikologis hal ini akan melahirkan kepribadian anak didik yang utuh (integrative personality).

Ketiga, masalah integrasi sarana dan prasarana. Sebagai pusat pembe-lajaran, pesantren atau madrasah dalam hal ini dituntut menciptakan keselarasan antara lingkungan sekitar. Sehingga akan tercipta situasi pembelajaran di kelas yang kondusif bagi pencapaian pembelajaran. Dari sini kemudian, integrasi sarana dan prasarana adalah bagaimana mebuat master plan mengenai tata ruang dan tata bangunan yang teratur, sehat, dan sesuai dengan standar kesehatan dan kebersihan.Keempat, integrasi manajemen. Sekurang-kurangnya ada tiga alasan kenapa manajemen dibutuhkan bagi pendidikan di pesantren, yaitu:

1) Untuk mencapai tujuan pendidikan yang diselenggarakan di pesantren

2) Untuk menjaga keseimbangan di antara tujuan-tujuan yang sering berseberangan dalam proses pendidikan yang berlangsung di dalam pesantren

3) Untuk mencapai efisiensi dan efektivitas dalam pengelolaan pendidikan di pesantren. $^{35}$

Dari gambaran di atas diketahui bahwa kesinambungan tujuan pendidikan Islam dalam setiap jenjang pendidikan sekolah (formal) sangatlah penting, dan itu

\footnotetext{
${ }^{34}$ Masnur Alam, Model Pondok Pesantren Moderen: Sebagai Alternatif Pendidikan Masa Kini Dan Mendatang, (Ciputat, Gaung Persada, 2011), 127

${ }^{35}$ MU YAPPI, Manajemen Pengembangan Pondok Pesantren, (Jakarta, Media Nusantara, 2008), 50
} 
akan mempengaruhi kemampuan anak didik dalam menjalani proses pendidikan. Untuk menjaga kesinambungan proses pendidikan, penjabaran capaian tujuan pendidikan melalui kurikulum pendidikan, dengan guru/ustadz dan budaya pendidikan yang mendukung menjadi suatu kebutuhan yang tidak terelakkan. Kurikulum pendidikan Islam sendiri sangatlah khas sebagai pedoman dalam pendidikan nasional.

Oleh karena itu, ada beberapa pointer yang menjadi perhatiandalam format pelaksanaan pendidikan berbasis pesantren, yaitu: pertama, Pembuatan strategi atau pendekatan yang komprehensif, seperti dalam hal keterbukaan dalam memahami norma keagamaan di pesantren, mempertahankan budaya pesantren yang baik, dan membuat skala prioritas dalam merancang program; kedua pengembangan visi dan misi pendidikan pesantren, baik dalam skala mikro maupun makro; ketiga dilakukannya integrasi antara tujuan pendidikan di pesantren dan madrasah, yaitu terciptanya SDM muslim yang terampil, cerdas, ikhlas, mandiri dan utuh, baik dalam sikap maupun tindakan. ${ }^{36}$ Sementara di pihak lain, dengan berbagi karakteristik yang dimilikinya, diharapkan lembaga pendidikan Islam akan dapat berperan dalam pengendalian sosial, terutama dalam konteks mencetak kepemimpinan agama di tengah masyarakat (religious commu-nity leader). Selanjutnya, pesantren juga diharapkan akan melahirkan keterpaduan kemampuan yang dimiliki anak didik (santri), yaitu sebagai seorang muslim yang saleh dan sekaligus memiliki kemampuan intelektual yang memadai, di samping penguasaan terhadap sains dan tekhnologi mumpuni. Inilah sosok lulusan pesantren dan sekaligus warga negara ideal yang memiliki integritas dan kapasitas, baik dalam melakukan analisis ilmiah, maupun concern-nya dalam mengatasi problem kemanusian dan sosial-kemasyarakatan yang selalu bermunculan di sepanjang waktu.

\section{Sinergisitas Pendidikan Islam Bersifat Integrasi-Holistik}

Prinsip pendidikan Islam berorientasi pada kemaslahatan didunia menuju kampung akhirat. Karena itu, mempersiapkan diri secara utuh merupakan hal yang tidak dapat dielakkan agar masa kehidupan di dunia ini benar-benar bermanfaat untuk bekal yang akan dibawa ke akhirat. Perilaku yang terdidik dan nikmat Tuhan apapun yang didapat dalam kehidupan harus diabdikan untuk mencapai kelayakan terutama dengan mematuhi keinginan Tuhan dalam syariat-Nya.Allah Swt Berfirman dalam surah al-Qoshosh ayat 77:

"Dan carilah pada apa yang telah dianugerahkan Allah kepadamu (kebahagiaan) negeri akhirat, dan janganlah kamu melupakan bahagianmu dari

\footnotetext{
${ }^{36} \mathrm{Ibid}$.
} 
(kenikmatan) duniawi dan berbuat baiklah (kepada orang lain) sebagaimana Allah telah berbuat baik, kepadamu, dan janganlah kamu berbuat kerusakan di (muka) bumi. Sesungguhnya Allah tidak menyukai orang-orang yang berbuat kerusakan."

Ayat tersebut menunjukkan kepada prinsip integritas di mana diri dan segala yang ada padanya dikembangkan pada satu arah, yakni kebajikan dalam rangka pengabdian kepada Tuhan.Integrasi adalah upaya memadukan ilmu umum dan ilmu agama (Islam). Integrasi ini dalam pandangan Amin Abdullah akan mengalami kesulitan dalam memadukan studi Islam dan umum yang kadang tidak saling akur karena keduanya ingin saling mengalahkan, oleh karena itu diperlukan adanya gagasan holistic (menyeluruh). ${ }^{37}$ Sedangkan Interkoneksi adalah usaha memahami kompleksitas fenomena kehidupan yang dihadapi dan dijalani manusia, setiap bangunan keilmuan apapun, baik keilmuan agama (termasuk agama Islam, dan agama-agama lain) keilmuan sosial, humaniora,maupun kealaman tidak dapat berdiri sendiri tanpa kerjasama, saling tegur sapa, saling membutuhkan, saling koreksi, dan saling berhubungan antardisiplin keilmuan. Pendekatan integratif-interkonektif adalah pendekatan yang berusaha saling menghargai; keilmuan umum dan agama sadar akan keterbatasan masing-masing dalam memecahkan persoalan manusia, hal ini akan melahirkan sebuah kerja sama setidaknya saling memahami pendekatan (approach) dan metode berpikir (process and procedure) antara kedua kelimuan tersebut. ${ }^{38}$

Lebih lanjut M. Amin Abdullah menjelaskan bahwa secara sistemik dalam sejarah kependidikan Islam dipandang sebagai tatanan pelaksanaan yang integralistik bersamaan dengan pola pengembangan keilmuannya. ${ }^{39}$ Secara pedagogis pendidikan Islam sebagai pengembang potensi dasar secara integral antara rohani dan jasmani untuk membentuk manusia muslim.Secara institusional pendidikan Islam adalah bentuk pendidikan yang berjenjang.Secara kurikuler pendidikan Islam mengarahkan seluruh komponen dan faktor-faktor pendukung pendidikan untuk mewujudkan citacita islami. Dengan pendekatan ini pendidikan menganggap manusia sebagai makhluk yang sedang mengalami proses pertumbuhan dan perkembangan baik secara jasmani dan rohani. ${ }^{40}$

Abuddin Nata, memahami bahwa prinsip integratik yang holistic dalam pendidikan Islam berupaya memahami pendidikan Islam yang terdiri dari berbagai

\footnotetext{
${ }^{37}$ M. Amin Abdullah, Islamic Studies Di Perguruan Tinggi: Pendekatan IntegratifInterkonektif, (Yogyakarta, Pustaka Pelajar, 2006), 94

${ }^{38}$ M. Amin Abdullah...,242

${ }^{39}$ Ibid.

40 Jasa Ungguh Muliawan, Pendidikan Integratif: Upaya Mengintegrasikan Kembali Dikotomi Ilmu Dan Pendidikan Islam, Yogyakarta, Pustaka Pelajar, 2005), 203
} 
lembaga pendidikan Islam itu sebagai satu kasatuan yang harus saling melengkapi dan menyempurnakan, bukan untuk dibeda-bedakan apalagi dipertentangkan antara satu sama lainnya. ${ }^{41}$ Implikasi terhadap pendapat di atas antara lain berusaha memadukan antara tradisi pesantren dan perguruan tinggi Islam. Menurut $\mathbf{M}$. Zainuddin upaya membangun sistem pendidikan yang integrasi sekaligus untuk menghindari keterputusan sejarah pendidikan Islam, membangun pribadi melalui pendidikan akan tepat jikaditempuh dengan cara bukan mengubah, tetapi meneruskan atau menyempurnakan. Selain itu juga kesatuan nilai dalam lembaga pendidikan Islam menunjukkan bahwa sebenarnya Islam itu adalah merupakan ajaran yang memiliki cakupan sedemikian luas. Islam bukan hanya merupakan ajaran yang bersifat terbatas, yaitu berisi tuntunan ritual dan sejenisnya, melainkan juga menganjurkan kepada umatnya agar (1) selalu mengingat Tuhan pada setiap waktu, (2) memikirkandan merenungkan penciptaan langit dan bumi atau mengembangkan sains. Dan (3) mengembangkan teknologi yang bermanfaat bagi kehidupan manusia.Konsep yang sedemikian indah itu diperoleh dari al Qur'an dengan sebutan ulul al-Baab. ${ }^{42}$

Upaya pencaharian bentuk perguruan tinggi Islam yang ideal sebenarnya juga dilatar belakangi oleh keprihatinan bahwa umat Islam di berbagai belahan dunia ternyata belum sepenuhnya meraih keunggulan.Keadaan yang demikian itu dipandang tidak sejalan dengan ajaran Islam yang sedemikian konprehensif dan indah.Diyakini bahwa ketertinggalan umat Islam, di antara salah satu sebabnya adalah oleh karena lembaga pendidikan Islam baru mengembangkan keilmuan yang terbatas, yakni pada aspek keagamaan.Oleh karena itu, kelembagaan pendidikan tinggi Islam harus kembali kepada ruh asalnya pada sistem pesantren.Selain itu, agar tidak kehilangan akar sejarah tradisi dan keilmuannya, maka perguruan tinggi Islam dipadukan dengan tradisi pesantren.Melalui bentuk pendidikan Islam dimaksud maka diharapkan melahirkan sarjana yang memiliki empat kekuatan, yaitu (1) kedalaman Spritual, (2) Keagungan Akhlak, (3) Keluasan Ilmu, dan (4) kematangan Profesional. $^{43}$

Kehadiran Perguruan Tinggi Islam di Indonesia didahului oleh Pesantren dan ternyata dari lembaga pendidikan Islam tradisional dimaksud mampu melahirkan ulama yang keilmuannya diakui dan dijadikan acuan oleh masyarakat, berbekalkan ilmu agama yang diperoleh dari pondok pesantren, ulama dimaksud menjadi

${ }^{41}$ Abuddin Nata, Manajemen Pendidikan Islam: Mengatasi Kelemahan Pendidikan Islam Di Indonesia, (Jakarta, Kencana, 2010), 341

${ }^{42}$ M. Zainuddin. Paradigma Pendidikan Terpadu, menyiapkan generasi ulul albab, (Malang: UIN-Malang Press, 2008), 5

${ }^{43}$ Imam Suprayogo..., 42 
pemimpin masyarakat, tokoh agama, melakukan peran-peran stragis lainnya di tengah masyarakat. Tidak sedikit tokoh Islam tingkat nasional sekarang ini, pernah mengenyam pendidikan pesantren. Dalam perkembangan lebih lanjut, sebagai upaya merespon tuntutan zaman modern, dari para ulama sendiri menginginkan ada lembaga pendidikan Islam yang mampu melahirkan sosok ulama yang sekaligus intelek, dan intelek yang sekaligus Ulama. Jika ulama dikonotasikan sebagai seorang lulusan pesantren, maka sebagai sosok intelek lahir dari perguruan tinggi pada umumnya. Keinginan tersebut ternyata menjadi kenyataan, bahwa secara bertahap berdiri lembaga pendidikan tinggi Islam, dan pada perkembangan selanjutnya, lembaga pendidikan tinggi dimaksud dikenal dengan sebutan Universitas Islam Negeri (UIN).Sistem yang dikembangkan dengan memadukan sistem pesantren dan perguruan tinggi Islam. Perguruan tinggi (universitas) menyediakan asrama (ma'had) dan mahasiswa mengikuti perkuliahan layaknya pada universiatas pada umumnya.

Hal ini, secara historis bahwa pada dasarnya lembaga pendidikanIslam lahir dari proses metamorposis sistem pendidikan pesantren. semua lembaga pendidikan Islam memiliki visi dan misi yang tidak jauh berbeda. Bahkan, pada tahapan kekinian, institusi pendidikan Islam memiliki peran yang sama, yaitu: Pertama, sebagai pusat berlangsungnya transmisi ilmu-ilmu Islam tradisional (transmission of islamis knowledge). Kedua, sebagai penjaga dan pemelihara keberlangsungan tradisi Islam (maintanance of islamic tradition); dan ketiga, sebagai pusat reproduksi ulama (reproduction of ulama). ${ }^{44}$ Ketiga peran ini menunjukkan, betapa antara pesantren dan perguruan tinggi Islam telah berhasil mensinergikan dan mewariskan nilai-nilai budaya, seperti nilai kebersaman, nilai kemandirian, dan nilai-nilai kemajuan dalam kehidupan berbangsa dan bermasyarakat.Konsep dan praktik integrasi-holistik sangat dibutuhkan untuk mempersempit ruang dualisme atau dikotomi ilmu yang memisahkan antara pendidikan umum dari pendidikan agama yang kemudian berdampak pada pemisahan dan pemilahan kesadaran keagamaan dan ilmu pengetauan umum. Hal ini pada tataran operasionalnya nampak pada pemisahan antara madrasah dan sekolah, mata pelajaran umum dan mata pelajaran agama,Fakultas Agama dan Fakultas Umum,dan lain-lain.

Dalam pandangan Islam, ilmu sudah terkandung secara esensial dalam alQur'an.Beragama berarti berilmu dan berilmu berarti beragama.Karena itu, tidak ada dikotomi antara agama dan ilmu.Tujuan pendidikan, menurut al-Qur'an, adalah untuk mengembangkan manusia menjadi pribadi yang kreatif, yang memungkinkan memanfaatkan sumber-sumber alam untuk kebaikan umat manusia dan untuk

${ }^{44}$ Azyumardi Azra, Pendidikan Islam: Tradisi Dan Modernisasi Menuju Millennium Baru, (Ciputat, Logos, 1999), 9 
menciptakan keadilan, kemajuan, dan keteraturan dunia.Paradigma ilmu pada Pendidikan Tinggi Islam meliputi berbagai kesadaran, yaitu: pertama, ilmu itu secara esensial terkandung dalam ajaran Islam. Pertumbuhan dan perkembangan suatu ilmu senantiasa bersumber dari nilai-nilai ajaran Islam.Kedua, Islam tidak mengenal dikotomi antara ilmu dan agama.Keduanya tidak dapat dipisahkan, tetapi dapat dibedakan dalam setiap posisi dan perannya.Kebenaran ilmu bersifat empirik dan relatif.Ketiga, ilmu itu diciptakan manusia.Hanya saja, sejak awal penciptaannya, pengembangan dan pengamalan ilmu sudah diniatkan untuk mengabdi kepada Sang Maha Pencipta. ${ }^{45}$

Dengan demikian, sasaran yang akan diperbaharui adalah pertama mental mau dibangun diganti dengan mental membangun, yang memiliki ciri-ciri (a) sikap terbuka, kritis, dan suka meneliti, (b) melihat ke depan, (c) teliti dalam bekerja, (d) mempunyai inisiatif dalam menggunakan metode-metode baru untuk berbuat sesuatu sekalipun anggota masyarakat lainnya belum atau tidak mempergunakannya, (e) lebih sabar dan tahan bekerja dan (f) bersedia bekerja sama dengan lembaga-lembaga lain. Kedua, reformasi kurikulum pondok pesantren, dan ketiga, pengajaran dan pendidikan yang berhubungan dengan ketrampilan kerja. Reformasi pondok pesantren diarahkan untuk jangka pendek supaya dapat mencukupi tenaga kerja tingkat rendah dan menengah, dan untuk jangka panjang, supaya dapat ikut aktif dalam pembangunan untuk menciptakan masyarakat adil makmur lahir batin.

\section{Penutup}

Pendidikan Islam yang berlangsung melalui proses operasional menuju tujuannya memerlukan model dan sistem yang konsisten yang dapat mendukung nilai-nilai moral-spiritual yang melandasinya. Nilai-nilai tersebut diaktualisasikan berdasarkan orientasi kebutuhan perkembangan fitrah murid (learner potensials orientation) yang dipadu dengan pengaruh lingkungan kultural yang ada. Karena itu, manajemen kelembagaan pendidikan Islam memandang bahwa seluruh proses kependidikan dalam institusi adalah sebagai suatu sistem yang berorientasi kepada perbuatan yang nyata.Upaya untuk mebangun sinergisitas pendidikan Islam sebagai pendidikan terpadu dalam sebuah program pendidikan yang memuat dua sistem sekaligus, antara pendidikan keluarga, masyarakat dan lembaga pendidikan formal seperti pesantren, madrasah dan sekolah dan perguruan tinggidiawali dengan melakukan integrasi, baik secara kultural maupun secara kelembagaan serta program. Sebuah institusi pendidikan, termasuk pesantren dan madrasah dan perguruan tinggi

\footnotetext{
${ }^{45}$ Imam Suprayogo...,45
} 
akan dikatakan efektif, manakala memiliki visi, misi, tujuan, sasaran, program peningkatan mutu, dan menghasilkan alumni yang mempunyai kompetensi yang memadai. Dengan demikian usaha di atas menjadi semacam tanggung jawab bersama di kalangan para penyelenggara pendidikan. Sehingga, tanggung jawab peningkatan mutu, misalnya, bukan sekedar agenda seorang pemimpin dalam lembaga pendidikan Islam, tetapi menjadi agenda bersama semua komponen organisasi penyelenggara pendidikan Islam, bahkan juga segenap masyarakat. Lebih dari itu, yang lebih penting lagi adalah pemahaman dan rasa tanggung jawab bersama semua penyelenggara pendidikan tentang hal berbagai komponen tersebut. Hal ini akan menjadi penting dalam rangka pelaksanaan program secara terarah, tepat dan cepat.

\section{DAFTAR PUSTAKA}

Abdullah, M. Amin. Islamic Studies Di Perguruan Tinggi: Pendekatan IntegratifInterkonektif (Yogyakarta: Pustaka Pelajar, 2006).

Abdul Fatah, Rohadi. Manajemen Pemberdayaan Masjid (Jakarta, Titian Kencana Mandiri, 2010).

Abdul Jawwad, Muhammad, Menjadi Manajer Sukses, (Jakarta, Gema Insani Press, 2000).

Alam, Masnur, Model Pondok Pesantren Moderen: Sebagai Alternatif Pendidikan Masa Kini Dan Mendatang, (Ciputat, Gaung Persada, 2011).

At-Thobari, Abi Ja'far Muhammad Bin Jarir, Tafsir At-Thobari, (Beirut, Darul Kutb Ilmiyah).

Azra, Azyumardi, Pendidikan Islam: Tradisi Modernisasi Menuju Melinium Baru, (Jakarta: Logos Wacana Ilmu, 1999), Cet. I. , Esei-Esei Intelektual Muslim \& Pendidikan Islam, (Jakarta, Logos Wacana Ilmu, 1998)

Daulay, Haidah Putra,Dalam Sistem Pendidikan Nasional Di Indonesia, (Jakarta,: Kencana Prenada Media Group, 2007).

Daradjat, Zakiah, dkk, Ilmu Pendidikan Islam, (Jakarta : Bumi Aksara, 1992)

Fajar, A. Malik, Holistik Pemikiran Pendidikan, (Jakart: Raja Grafindo Persada, 2005)

Faisal, Jusuf Amir, Reorientasi Pendidikan Islam, (Jakarta, Gema Insani Press, 1995).

Haedari, HM. Amin, Pesantren Dan Peradaban Islam, ((Jakarta: Puslitbang Kemenag RI, 2010).

............. H.M. Amin, Pendidikan Agama Islam Di Indonesia: Gagasan Dan Realitas, (Jakarta: Puslitbang Kemenag RI, 2010)

Hasbullah, Kapita Selekta Pendidikan Islam di Indonesia, (Jakarta; Raja Grafindo Persada, 1996)

Huda, Nor, Sejarah Social Intelektual Islam, (Jakarta: Radjawali Press, 2015), Cet. I.

Getteng, Abd. Rahman, Pendidikan Islam Dan Pembangunan, (Ujung Pandang: Yayasan Ahkam; 1997).

Kementerian Pendidikan dan Kebudayaan RI, Direktorat Jenderal Pendidikan Dasar dan Menengah, Direktorat Pembinaan SMP, Laporan Monitoring dan Evaluasi Program Sekolah Berbasis Pesantren (Jakarta: Kemendikdasmen, 2016) 
Tajdid: Jurnal Pemikiran Keislaman dan Kemanusiaan Vol. 3 No. 2 Oktober 2019

Langgulung, Hasan, Beberapa Pemikiran Tentang Pendidikan Islam, (Bandung: AlMa'rif; 1980).

Maksum, Madrasah: Sejarah Dan Perkembanganny (Jakarta: Logos Wacana Ilmu, 1999)

Mujib, Abdul, dan Mudzakkir, Jusuf, Ilmu Pendidikan Islam, (Jakarta: Kencana, 2008), Cet ke 2.

Muhaimin, Pemikiran Dan Aktualisasi Pengembangan Pendidikan Islam, (Jakarta: Rajawai Press, 2012).

............., Nuansa Baru Pendidikan Islam: Mengurai Belang kusut Dunia Pendidikan, (Jakarta: Radja Grafindo Persada, 2006)

..............Arah Baru Pengembangan Pendidikan Islam (Bandung, Nuansa , 2003)

Mislaini, Khazanah Ilmu PendidikanIslam, (Padang: Hayfa Press, 2016).

Muliawan, Jasa Ungguh, Pendidikan Integratif: Upaya Mengintegrasikan Kembali Dikotomi Ilmu Dan Pendidikan Islam, Yogyakarta, Pustaka Pelajar, 2005).

M. Zainuddin. Paradigma Pendidikan Terpadu, menyiapkan generasi ulul albab, (Malang: UIN-Malang Press, 2008)

M. Echols, John,dan Shadily, Hassan, Kamus Inggris-Indonesia (Cet. 29; Jakarta: PT. Gramedia, 2007)

Munawwar, Ahmad Warson, Al-Munawwir,Kamus Arab Indonesia (Cet. 14; Surabaya: Pustaka Progressif, 1997)

MU YAPPI, Manajemen Pengembangan Pondok Pesantren, (Jakarta: Media Nusantara, 2008)

Nata, Abuddin, Paragigma Baru Pendidikan Islam Di Era Pasar Bebas, Dalam Buku, Reformulasi Pendidikan Islam Menghadapi Pasar Bebas, (Samsul Nizar (editor), Jakarta: The Minangkabau Foundation, 2005)

Kapita Selekta Pendidikan Islam: Isu-Isu Kontemporer Tentang

Pendidikan Islam, (Jakarta: PT. Radja Grafindo Persada, 2013)

Sejarah Sosial Intelektual Muslim Dan Institusi Pendidikannya, (Jakarta: Rajawali Press, 2012) ,Ilmu Pendidikan Islam, (Jakarta, Kencana, 2010)

................, Sejarah Pendidikan Islam Pada Periode Klasik dan Pertengahan, (Jakarta: PT. Raja Grafindo Persada, 2004).

................, Manajemen Pendidikan Islam: Mengatasi Kelemahan Pendidikan Islam Di Indonesia, (Jakarta, Kencana, 2010)

Puswadarminta, W.J.S., Kamus Umum Indonesia, (Jakarta: Balai Pustaka, (1976).

Qamar, Mujammil, Menggagas Pendidikan Islam, (Bandung: Remaja RosdaKarya, 2014)

Ramayulis, Ilmu Pendidikan Islam, (Jakarta: Kalam Mulia, 199).

Rehani, Berawal Dari Keluarga: Revolusi Belajar Cara Al-Qur'an, (Jakarta, Hikmah, 2003).

Solihin, Ismail, Manajemen Strategik, (Jakarta: Erlangga, 2012).

Suprayogo, Imam, Membangun Integrasi Ilmu Dan Agama: Pengembangan UIN Maliki Malang (proceeding), (Batusangkar, STAIN Batusangkar, 2016

Umar, Bukhari, Ilmu Pendidikan Islam, (Jakarta: Amzah, 2010), Cet. I

Ulwān, Abdullāh Naşih, Tarbiyah al-Awlād fì al-Islām, Juz 2 (Cet. 21; Jeddah: Dār al-Salām, 1412 H./1992 M.).

Wajoeotomo, Perguruan tinggi Pesantren, (Jakarta: GemaInsani Press, 1977) 